\title{
Development and Validation of Retirement Anxiety Scale for Secondary School Teachers in Osun State, Nigeria
}

\author{
Adeyemo Emily Oluseyi ${ }^{1} \&$ Olatomide Onijuni Olufemi ${ }^{1}$ \\ ${ }^{1}$ Dept of Educational Foundations and Counselling, Faculty of Education, Obafemi Awolowo University, Ile-Ife, \\ Nigeria \\ Correspondence: Adeyemo Emily Oluseyi, Dept of Educational Foundations and Counselling, Faculty of \\ Education, Obafemi Awolowo University, Ile-Ife, Nigeria. E-mail: seyiadeyemo2007@yahoo.com
}

Received: November 25, 2014

Accepted: January 17, $2015 \quad$ Online Published: May 29, 2015

doi:10.5539/ijps.v7n2p138

URL: http://dx.doi.org/10.5539/ijps.v7n2p138

\begin{abstract}
The study conducted a factor analysis of Retirement Anxiety Scale (RAS) for secondary school teachers. It developed a set of appropriate and homogeneous items on retirement anxiety suitable for Nigerian school teachers. It also determined the reliability indices of the scale and established its factor structure. The study population comprised all secondary school teachers in Osun state. Teachers that had less than ten years to retire from the service were the targeted population. A sample size of 204 teachers was purposively selected from four randomly selected local government of the state, based on the years left in service. The selected teachers completed the Retirement Anxiety Scale (RAS). The result was subjected to Principal Component Analysis with varimax rotation (PCA). The results of the PCA revealed that the communality $\mathrm{h}^{2}$ of each item was more than 0.5 , which implied a satisfactory quality. The KMO $>0.8$ showed that the data were sufficiently enough to undergo factor analysis, while the Barlett sign $\mathrm{p}<0.001$ revealed a sensible PCA. The reliability coefficient Cronbach $\alpha$ was statistically significant (0.863) indicating a high degree of internal consistency. The study concluded that the RAS instrument was valid and reliable for measuring retirement anxiety among secondary school teachers and also found suitable for Nigerian schools. The six-components released by the PCA could be used as a guide for school counsellors in pre-retirement counselling of secondary school teachers.
\end{abstract}

Keywords: retirement, anxiety, validation, scale, principal component analysis.

\section{Introduction}

In everyday life, the way an individual perceives an event, whether favourably or unfavourably, could generate diverse changes within the individual, which may lead to physiological, mental or emotional changes. Any of these changes could result in anxiety for the individual. Anxiety could be seen as a feeling of unease, apprehension or worry which may be associated with physical symptoms such as rapid heartbeat, feeling faint and trembling; it can also be a normal reaction to stress or worry, or sometimes a part of a bigger problem. Alken (1976) has described anxiety as a state of arousal that comes through bodily, emotional and mental changes which an individual encounters when facing a stimulus. Anxiety, therefore, could further be seen as a state of heightened alertness arising from uncertainty. It does appear that every human endeavour or engagement of importance where uncertainty is involved could attract anxiety: going for a medical check, embarking on a journey, going for an examination, preparing for a wedding, plunging one's resources or borrowing to pursue a business transaction, etc. One of the situations that could engender anxiety for workers is going into retirement.

Retirement has been described variously by different researchers. To Manion (1976), retirement is a complex social phenomenon of modern industrial society which defines a person as being old and therefore requires withdrawal from customary activity in business, industry, or service. It is also a termination of a pattern of life or the end of an employment or completion of a career which has won someone renown, and movement into a new beginning in the future (Akinade, 1993). A number of factors like old age, ill-health, unhappiness with conditions of service, familiar considerations, rules of the job, etc., could motivate retirement (Quadagno, 2002; Wolcott, 1998). According to Akpochafo (2005), the time of approaching retirement for workers has generally been identified as a source of worry, anxiety and stress, which could be as a result of uncertainties regarding life after retirement. Relatedly, retirement anxiety can be described as feeling of intense fear, discomfort, and uncertainties that consistently interfere with prospective retirees' thought processes and preparations towards 
their retirement. It is characterised by both positive and negative emotions, depending on how the retirement-eligible retirees perceive their pre-retirement preparation, whether adequate or otherwise, as well as their view on the adequacy and consistency of their employers in some aspects of their post-retirement needs.

It does appear that any area of perceived need in retirement that any eligible retiree has not adequately prepared for could induce anxiety. Relatedly, Olatomide and Akomolafe (2012) explored the pre-retirement guidance needs of primary school teachers approaching retirement and found, in order of relative importance, that: locating income-returning ventures that require little capital to setup, work-substitute in retirement, wisdom in financial management, the advantages retirement could offer, healthy living guides, expanding social network, time management skills, how to involve family members in pre-retirement planning, social acceptance and relevance within the community, continued relevance to the family, decision-making skills, effective ways of handling family idiosyncrasies, and reading materials to warm the brain are potential pre-retirement guidance needs of the respondents as they draw near their retirement.

In Nigeria, as workers advance towards retirement, they go through both positive and negative emotions. Nsirimobi and Ajuwede (2005), stated that pre-retired workers in Nigeria perceived retirement as a punitive outcome, which must be avoided; and that they become shivery at the approach of retirement. This underpins pre-retirement nervousness. Similarly, Denga (1996), as well as Okorodudu (1998), submitted that pre-retired workers experience uncertainty, having analytically assessed and evaluated themselves in respect to their goals, in order to determine if they have achieved their work goals or otherwise. In addition, Nsirimobi and Ajuwede (2005) found that as workers advance towards retirement, they exhibit lack of motivation about their retirement preparedness. This is because, even for most of them who possess effective pre-retirement skills that could enhance their retirement adjustment, they go through absence of pre-retirement motivation and adjustment, presumably due to lack of expert's guidance on effective pre-retirement preparation to validate their skills. Each of these is an example of negative pre-retirement emotions. On the other side, prospective retirees also go through positive emotions. Nsirimobi and Ajuwede (2005) submitted that retirement-eligible workers in the well-organised private sectors view retirement as a pleasant experience, and earnestly look forward to its coming due to employer-organised post-retirement preparations, especially in the area of finance. This is an example of pre-retirement preparation excitement. Similarly, both Denga (1986) and Okpede (1998) agreed that as workers are close to retirement, the well-prepared ones (though relatively few), exhibit security-induced confidence, which propel them to look towards their eventual retirement with eagerness and demonstrated easiness. Each of these is an example of negative emotions towards retirement preparedness.

In Nigeria, some researchers appear in the literature to have worked on pre-retirement anxiety of workers as they approached retirement, for instance, Clifford, Ogbebor, and Enakpoya (2010) as well as Akpochafo (2005), or their pre-retirement guidance, for instance, Olatomide and Akomolafe (2012), including Eyitayo, Lucy, and Obadofin (2008). Interestingly, however, to the best knowledge of these researchers, none of these studies delved into development and validation of anxiety scale for Nigerian workers, especially among the secondary school teachers. There is the need, therefore, to develop a high psychometric quality instrument on retirement anxiety that is most appropriate for Nigerian setting.

The objectives of these studies were to:

(1) Develop appropriate and homogeneous items on retirement anxiety that is suitable for Nigerian Schools

(2) Determine the reliability indices of the scale and

(3) Establish the factor structure of the scale

\section{Method}

This study employed survey design to investigate secondary school teachers retirement anxiety and to obtain accurate data of high response The study population consisted of all Secondary school teachers in Osun state. Teachers that have less than ten years to retire were the targeted population. The sample size consisted of 204 teachers purposively selected on the basis of years in service from four randomly selected local governments of the state. As the first step towards the development of the retirement anxiety scale (RAS), 24 positive and negative statements that expressived anxiety towards retirement were written after a careful study of related literature on anxiety and practical experience retrieved from retiree. These questions which were of a 5-point Likert scale were administered to 204 teachers that had below 10 years to retire from the service. Principal Component Analysis with Varimax Rotation which produced the dimension of differentiation was used on the data to determine the suitability of the scale on factor analysis. The Kaise-Meyer Olkin measure (KMO) of sampling adequacy was employed to determine the sample sufficiency. The criterion of Eigen value or 
characteristics root (Eigen value $\geq 1$ ) was used to determine the number of factors that were kept. The evaluation of the questionnaire reliability internal consistency was made possible by Cronbach $\alpha$ which was considered the most important reliability index and was based on the number of the variable or items of the questionnaire as well as the correlations between the variables

\section{Results}

Objective 1: Development of an appropriate and homogeneous items on retirement anxiety that is suitable for Nigerian Schools

Table 1 presents the initial items on the Retirement Anxiety Scale (RAS). The twenty four items relating to retirement anxiety were administered on 204 participants. This scale consisted of both positive and negative items. The responses were analyzed using percentages. Items 12 and 24 were the same; hence item 24 was removed leaving a total of 23 items resulting to 12 positive and 11 negative items

Table 1. Retirement Anxiety Scale (RAS)

\begin{tabular}{|c|c|c|c|c|}
\hline Items & Agree & Disagree & Undecided & Total \\
\hline Retirement thought make me feel comfortable and easy & 80.4 & 12.3 & 7.4 & 204 \\
\hline $\begin{array}{l}\text { Retirement thought make me look forward to my retirement } \\
\text { with happiness }\end{array}$ & 85.8 & 6.9 & 7.4 & 204 \\
\hline I feel that retirement will be most pleasant period for me & 91.7 & 2.9 & 5.4 & 204 \\
\hline I feel calm when I think about the approaching retirement & 70.6 & 17.2 & 12.3 & 204 \\
\hline $\begin{array}{l}\text { My mind goes blank when I am asked how well I have } \\
\text { prepared for my retirement }\end{array}$ & 32.8 & 53.9 & 13.2 & 204 \\
\hline $\begin{array}{l}\text { I find reading materials on how to prepare for retirement } \\
\text { interesting to me }\end{array}$ & 78.9 & 13.2 & 7.8 & 204 \\
\hline I find it enjoyable asking retirees how to prepare for retirement & 85.8 & 6.9 & 7.4 & 204 \\
\hline $\begin{array}{l}\text { I experience pleasantness when I feel my retirement could } \\
\text { come forward by some years than expected }\end{array}$ & 58.3 & 27.9 & 13.7 & 204 \\
\hline $\begin{array}{l}\text { Seeing a retiree that I know gives me fear about my } \\
\text { approaching retirement }\end{array}$ & 34.8 & 58.8 & 6.4 & 204 \\
\hline $\begin{array}{l}\text { I feel relaxed when I am about doing something positive in } \\
\text { preparation for my retirement }\end{array}$ & 84.3 & 11.8 & 3.9 & 204 \\
\hline $\begin{array}{l}\text { I find collating my records of service an interesting activity for } \\
\text { me }\end{array}$ & 71.6 & 13.2 & 15.2 & 204 \\
\hline $\begin{array}{l}\text { I am scared about discussing the preparation of my retirement } \\
\text { with members of my family }\end{array}$ & 17.6 & 74.5 & 7.8 & 204 \\
\hline Retirement thoughts make me feel uncomfortable and uneasy & 15.2 & 78.9 & 5.9 & 204 \\
\hline $\begin{array}{l}\text { Retirement thought make me look forward to my retirement } \\
\text { with sadness }\end{array}$ & 6.4 & 85.3 & 8.3 & 204 \\
\hline I feel that retirement will be most dreaded period for me & 6.9 & 82.4 & 10.8 & 204 \\
\hline I feel nervous when I think about the approaching retirement & 14.7 & 78.4 & 6.9 & 204 \\
\hline $\begin{array}{l}\text { My mind is filled with answers when I am asked how well I } \\
\text { have prepared for my retirement }\end{array}$ & 68.6 & 20.1 & 11.3 & 204 \\
\hline $\begin{array}{l}\text { Reading materials on how to prepare for retirement gives me } \\
\text { headache }\end{array}$ & 12.3 & 79.9 & 7.8 & 204 \\
\hline $\begin{array}{l}\text { I am afraid to ask questions from retirees on how to prepare for } \\
\text { retirement }\end{array}$ & 9.3 & 85.3 & 5.4 & 204 \\
\hline $\begin{array}{l}\text { I become nervous when I feel my retirement could come } \\
\text { forward by some years than expected }\end{array}$ & 25.5 & 65.2 & 9.3 & 204 \\
\hline
\end{tabular}




$\begin{aligned} & \text { Seeing a retiree that I know make me look forward to my } \\ & \text { retirement with happiness }\end{aligned}$
$\begin{aligned} & \text { I feel nervous when I am about doing something positive in } \\ & \text { preparation for my retirement }\end{aligned}$
$\begin{aligned} & \text { I find collating my records of service an uninteresting activity } \\ & \text { for me }\end{aligned}$
$\begin{aligned} & \text { I am scared about discussing the preparation of my retirement } \\ & \text { with members of my family }\end{aligned}$

Objective 2: To determine the reliability indices of the retirement anxiety scale suitable for secondary school teachers in Osun state

Table 2. Reliability indices of Retirement Anxiety Scale

\begin{tabular}{|c|c|c|c|}
\hline Anxiety Items & Dimension & $\begin{array}{l}\text { Correlation } \\
\text { Total }\end{array}$ & $\begin{array}{l}\text { Cronbach } \\
\text { Alpha }\end{array}$ \\
\hline Retirement thought make me feel comfortable and easy & Positive & 0.461 & 0.856 \\
\hline $\begin{array}{l}\text { Retirement thought make me look forward to my retirement with } \\
\text { happiness }\end{array}$ & Positive & 0.536 & 0.855 \\
\hline I feel that retirement will be most pleasant period for me & Positive & 0.488 & 0.856 \\
\hline I feel calm when I think about the approaching retirement & Positive & 0.359 & 0.860 \\
\hline $\begin{array}{l}\text { My mind goes blank when I am asked how well I have prepared } \\
\text { for my retirement }\end{array}$ & Negative & 0.361 & 0.860 \\
\hline $\begin{array}{l}\text { I find reading materials on how to prepare for retirement } \\
\text { interesting to me }\end{array}$ & Positive & 0.190 & 0.865 \\
\hline I find it enjoyable asking retirees how to prepare for retirement & Positive & 0.160 & 0.865 \\
\hline $\begin{array}{l}\text { I experience pleasantness when I feel my retirement could come } \\
\text { forward by some years than expected }\end{array}$ & Positive & 0.260 & 0.864 \\
\hline $\begin{array}{l}\text { Seeing a retiree that I know gives me fear about my approaching } \\
\text { retirement }\end{array}$ & Negative & 0.509 & 0.855 \\
\hline $\begin{array}{l}\text { I feel relaxed when I am about doing something positive in } \\
\text { preparation for my retirement }\end{array}$ & Positive & 0.319 & 0.861 \\
\hline I find collating my records of service an interesting activity for me & Positive & 0.311 & 0.861 \\
\hline $\begin{array}{l}\text { I am scared about discussing the preparation of my retirement } \\
\text { with members of my family }\end{array}$ & Negative & 0.558 & 0.853 \\
\hline Retirement thoughts make me feel uncomfortable and uneasy & Negative & 0.594 & 0.852 \\
\hline $\begin{array}{l}\text { Retirement thought make me look forward to my retirement with } \\
\text { sadness }\end{array}$ & Negative & 0.640 & 0.851 \\
\hline I feel that retirement will be most dreaded period for me & Negative & 0.597 & 0.853 \\
\hline I feel nervous when I think about the approaching retirement & Negative & 0.628 & 0.850 \\
\hline $\begin{array}{l}\text { My mind is filled with answers when I am asked how well I have } \\
\text { prepared for my retirement }\end{array}$ & Positive & 0.165 & 0.866 \\
\hline $\begin{array}{l}\text { Reading materials on how to prepare for retirement gives me } \\
\text { headache }\end{array}$ & Negative & 0.568 & 0.853 \\
\hline $\begin{array}{l}\text { I am afraid to ask questions from retirees on how to prepare for } \\
\text { retirement }\end{array}$ & Negative & 0.484 & 0.856 \\
\hline I become nervous when I feel my retirement could come forward & Negative & 0.557 & 0.853 \\
\hline
\end{tabular}


by some years than expected

Seeing a retiree that I know make me look forward to my retirement with happiness

Positive $\quad 0.445 \quad 0.857$

I feel nervous when I am about doing something positive in preparation for my retirement

Negative $\quad 0.471 \quad 0.856$

I find collating my records of service an uninteresting activity for me

Negative $\quad 0.360 \quad 0.860$

Total Cronbach $\alpha$ Reliability test

0.863

From Table 2 none of the items had a Cronbach Alpha that was less than 0.800 . These revealed that the reliability index of the items was high. The overall total Cronbach Alpha Reliability test was 0.863. This implied an overall high reliability index of all the items that constitute the Retirement Anxiety Scale

Objective 3: To establish the factor structure of the Retirement Anxiety Scale suitable for Secondary School teachers in Osun state

Table 3. Factor structure of Retirement Anxiety Scale

\begin{tabular}{|c|c|c|c|c|c|c|c|}
\hline Factor Analysis & F1 & F2 & F3 & F4 & F5 & F6 & Communality \\
\hline $\begin{array}{l}\text { Retirement thought make me feel comfortable } \\
\text { and easy }\end{array}$ & & & 0.659 & & & & 0.583 \\
\hline $\begin{array}{l}\text { Retirement thought make me look forward to } \\
\text { my retirement with happiness }\end{array}$ & & & 0.747 & & & & 0.727 \\
\hline $\begin{array}{l}\text { I feel that retirement will be most pleasant } \\
\text { period for me }\end{array}$ & & & 0.539 & & & & 0.526 \\
\hline $\begin{array}{l}\text { I feel calm when I think about the approaching } \\
\text { retirement }\end{array}$ & & & 0.683 & & & & 0.531 \\
\hline $\begin{array}{l}\text { My mind goes blank when I am asked how } \\
\text { well I have prepared for my retirement }\end{array}$ & 0.676 & & & & & & 0.557 \\
\hline $\begin{array}{l}\text { I find reading materials on how to prepare for } \\
\text { retirement interesting to me }\end{array}$ & & & & $\begin{array}{l}0.80 \\
9\end{array}$ & & & 0.676 \\
\hline $\begin{array}{l}\text { I find it enjoyable asking retirees how to } \\
\text { prepare for retirement }\end{array}$ & & & & $\begin{array}{l}0.80 \\
1\end{array}$ & & & 0.663 \\
\hline $\begin{array}{l}\text { I experience pleasantness when I feel my } \\
\text { retirement could come forward by some years } \\
\text { than expected }\end{array}$ & & & 0.496 & & & & 0.463 \\
\hline $\begin{array}{l}\text { Seeing a retiree that I know gives me fear } \\
\text { about my approaching retirement }\end{array}$ & 0.721 & & & & & & 0.667 \\
\hline $\begin{array}{l}\text { I feel relaxed when I am about doing } \\
\text { something positive in preparation for my } \\
\text { retirement }\end{array}$ & & $\begin{array}{l}0.41 \\
2\end{array}$ & & & & & 0.481 \\
\hline $\begin{array}{l}\text { I find collating my records of service an } \\
\text { interesting activity for me }\end{array}$ & & & & & & $\begin{array}{l}0.65 \\
6\end{array}$ & 0.677 \\
\hline $\begin{array}{l}\text { I am scared about discussing the preparation of } \\
\text { my retirement with members of my family }\end{array}$ & 0.723 & & & & & & 0.633 \\
\hline $\begin{array}{l}\text { Retirement thoughts make me feel } \\
\text { uncomfortable and uneasy }\end{array}$ & 0.597 & & & & & & 0.632 \\
\hline $\begin{array}{l}\text { Retirement thought make me look forward to } \\
\text { my retirement with sadness }\end{array}$ & 0.551 & $\begin{array}{l}0.48 \\
5\end{array}$ & & & & & 0.646 \\
\hline
\end{tabular}


I feel that retirement will be most dreaded 0.552 0.654 period for me

I feel nervous when I think about the approaching retirement

My mind is filled with answers when I am asked how well I have prepared for my retirement

Reading materials on how to prepare for retirement gives me headache

I am afraid to ask questions from retirees on how to prepare for retirement

I become nervous when I feel my retirement could come forward by some years than expected

Seeing a retiree that I know make me look forward to my retirement with happiness

I feel nervous when I am about doing something positive in preparation for my retirement

I find collating my records of service an uninteresting activity for me

Eigen Value

$\%$ of total variance

Cumulative $\%$ of Variances
0.55

9

$\begin{array}{lll}0.81 & 0.681 \\ 4 & \end{array}$

0.68

4

0.72

0.575

6

0.58

0.492

7

$\begin{array}{llllll}6.399 & 2.17 & 1.528 & 1.24 & 1.12 & 1.07 \\ & 4 & & 8 & 7 & 0 \\ 27.82 & 9.45 & 6.64 & 5.43 & 4.90 & 4.65 \\ 27.82 & 37.2 & 43.92 & 49.3 & 54.2 & 58.8 \\ & 7 & & 4 & 4 & 9\end{array}$

Cronbach $\alpha(\%)$

Total cronbach $\alpha(\%)$

Note. Kaiser-Meyer-Olkin Measure (KMO) of sampling adequacy $=0.841$

Bartlett's test of sphericity: $\chi^{2}=1544.730 ; \mathrm{df}=254 ; \mathrm{p}<0.001$

Twenty three questions relating to retirement anxiety scale (RAS) using Principal Component Analysis (PCA) with a varimax (orthogonal) rotation was conducted on data gathered from 214 participants. The analysis yielded six factors explaining a total of $58.89 \%$ of the variance for the entire set of variables. An examination of the Kaiser-Meyer Olkin measure of sampling adequacy suggested that the sample was factorable $(\mathrm{KMO}=0.84)$ with the Bartlett's Test of Sphericity less than 0.05 .

The results of an orthogonal rotation of the solution were as shown in the Table three above. When loadings less than 0.40 were excluded, the analysis yielded a six-factor solution with a simple structure (factor loadings $\geq$ 0.40). The variables loading onto each of the six-factor solution are explained below.

Seven items loaded on factor one (F1) which explained $27.82 \%$ of the variance, seven items loaded on factor two (F2) which explained $9.45 \%$ of the total variance, five items loaded on factor three (F3) which explained $6.64 \%$, two items loaded on factor four (F4) which explained $5.43 \%$, two items loaded on factor five (F5) which explained $4.90 \%$ and two items loaded on factor six (F6) which explained $4.65 \%$ of the total variance.

Some of the items such as "seeing a retiree that I know make me look forward to my retirement with happiness" loaded on F5 and F6, "retirement thought make me look forward to my retirement with sadness" loaded on F1 and F2 had factor loadings greater than 0.40 .

The communality of each of the variables included is relatively high (more than 0.40 ) except "I feel nervous when I am about doing something positive in preparation for my retirement" whose communality is lower (0.396), having a small amount of variance in common with other variables in the analysis. 


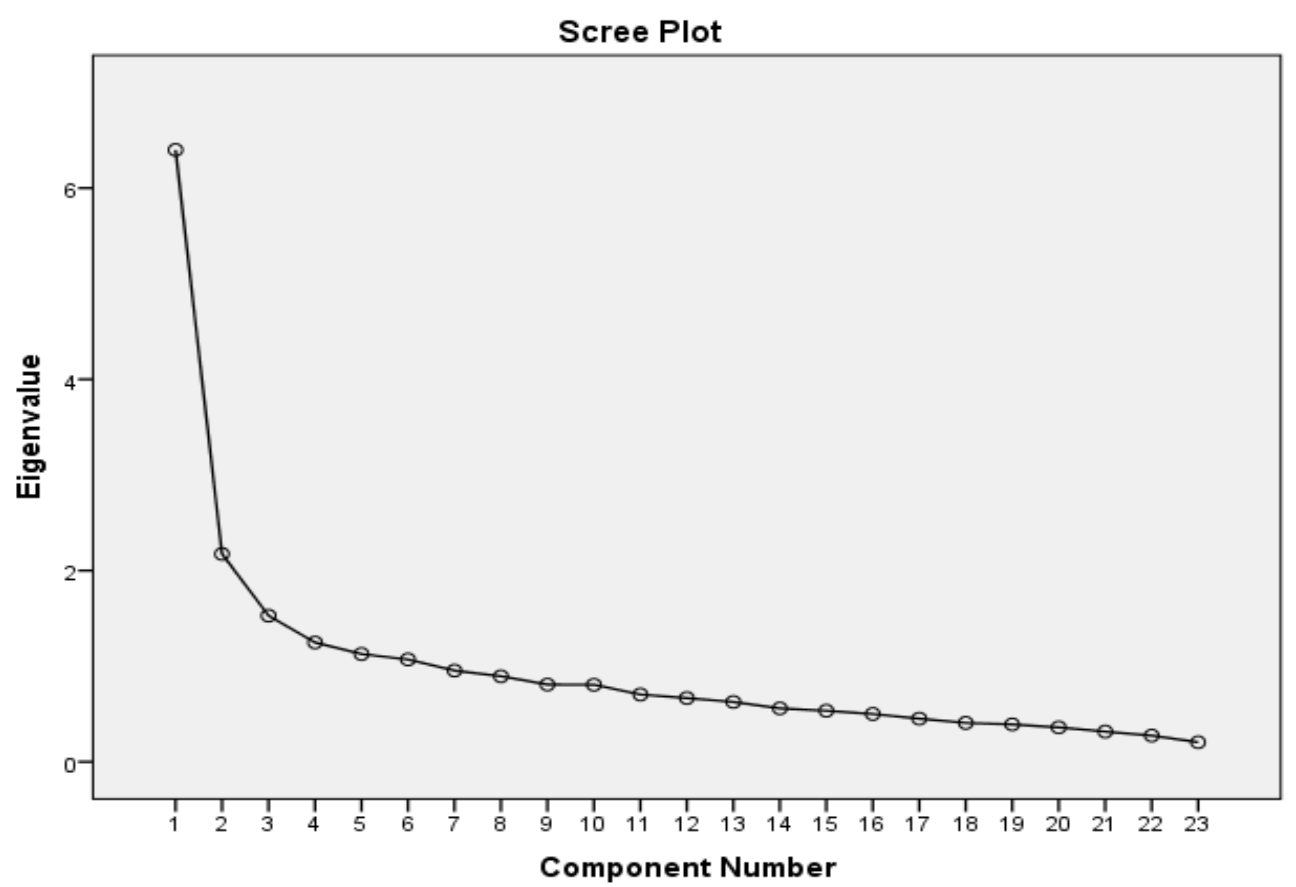

Figure 1. Scree plot on Retirement Anxiety Scale

The scree plot (Figure 1) further revealed the relevance of each factor in the entire components of the analysis. The eigen value is plotted against the number of components included in the analysis. As shown in the figure, the eigen value was above 1.00 only among the first six factors, indicating that only six factors have significant contribution in the items used for the analysis.

\section{Discussion}

The rating of the 24 items Retirement Anxiety Scale (RAS) for Secondary School teachers first led to the rejection of one item as a result of duplication. The item rejected was item 24 which is the same item with item 12. All the negative items were rated low on the 5-point Likert Scale while the positive items were rated high by the respondents, indicating the homogeneity and appropriateness of the item. Except for item 22 the communality $\mathrm{h}^{2}$, of each item was more than 0.5 , which revealed a satisfactory quality of the 6 -factor component model, therefore the scale satisfied the condition as stated by Rumel (1970).

The sample sufficiency index $(\mathrm{KMO})>0.8$ showed that the sample data were sufficient to undergo factor analysis and sphericity test (Barlett's sign $\mathrm{p}<0.001$ also showed that the principal component analysis was sensible). Through this analysis, data were grouped on the basis of their in-between correlations aiming at sorting out those factors which clearly described teacher's attitudes to the object of the research (retirement anxiety). The principal component analysis released six components which jointly attributed to $58.89 \%$ of the total variance. These components were found to be related with and classified as F1 = sense of Nervousness, F2 $=$ Uncertainty, F3 = Easiness, F4 = Motivation, F5 = Confidence, F6 = Excitement with the overall reliability coefficient Cronbach $\alpha$ statistically significant (0.863) indicating a high degree of internal consistency for group analysis which is acceptable as cited in Anastasi and Urbina (1998).

The high internal consistency of the Retirement Anxiety Scale (RAS) also suggested that the 24 items even though bi-dimensional (12-positive, 12-negative) turned out to be an internally consistent measure of retirement anxiety scale construct which the respondent's responses were highly reliable, stable and true measurement of anxiety retirement rating because the higher the value of the more reliable the test. Thus this follows the rule of thumb for the values $>0.9=$ excellent, $>0.8=$ good, $>0.7$ acceptable, $>0.6$ questionable, $>0.5$ poor, $<0.5$ unacceptable George and Mallary (2003).

\section{Conclusion}

From this study, results indicated that the Retirement Anxiety Scale (RAS) that was developed and validated was a valid and reliable instrument for measuring retirement anxiety among secondary school teachers and was also 
found to be suitable for Nigerian schools. The six-components released by the Principal Component Analysis (PCA) which were tagged senses of Nervousness, Uncertainty, Easiness, Motivation, Confidence and Excitement would help the school counsellors in pre-retirement counselling of secondary school teachers.

\section{References}

Akinade, E. A. (1993). Towards satisfactory retirement: A sociopsychological approach. Lagos, Nigeria: Kola Okanlawon Services Ltd.

Akpochafo, G. O. (2005). A comparative study of anxiety associated with pre-retirement uncertainties of public and private workers: Implications for counselling. The Counsellor, 21, 146-155.

Clifford, S. D. O., Ogbebor, G. G., \& Enakpoya, E. E. (2010). Retirement anxiety and counselling needs of pre-retirees in Delta State. The Counsellor, 27, 76-82.

Denga, D. I. (1986). Guidance and counselling in school and non-school settings. Calabar, Nigeria: Centaur Press.

Eyitayo, A. C., Lucy, I. B., \& Obadofin, B. (2008). Ascertaining post retirement counselling preferences of workers in selected areas of Lagos metropolis. In E. A. Akinade (Ed.), Proceedings of the 23rd Annual Conference of CASSON (pp. 81-89).

George, D., \& Mallery, P. (2003). SPSS for windows step by step: A simple guide and reference 11.0 update (4th ed.). Boston, M A: Allyn and Bacon.

Manion, V. U. (1976). Pre-retirement. The Personnel Guidance Journals, 55(3), 119-121. http://dx.doi.org/ 10.1002/j.2164-4918.1976.tb04426.x

Nsirimobi, O. S., \& Ajuwede, I. M. (2005). Effectiveness of group counselling and bibliography on workers' pre-retirement adjustment in Port-Harcourt Local Government Area of Rivers State. The Counsellor, 21, 136-145.

Okorodudu, I. R. (1998). Counselling for retirement in an unstable economy. The Counsellor, 16(1), 88-96.

Okpede, E. O. D. (1998). Counselling in governmental setting. Jos, Nigeria: Mono Expression Ltd.

Olatomide, O. O., \& Akomolafe, M. J. (2012). Assessment of pre-retirement guidance needs of near-retirement teachers in public primary schools in Ondo State, Nigeria. Ife Journal of Educational Leadership, Administration and Planning, 1(1), 107-116.

Quadagno, J. (2002). Aging and life course: An introduction to social Gerontology (2nd ed.). New York: John Willey.

Rumel, R. J. (1970). Applied Factor Analysis. Evanston: North-western University Press.

Wolcott, I. (1998). Families in later life: Dimensions of retirement. Australia: Australian Institute of Family Studies.

\section{Copyrights}

Copyright for this article is retained by the author(s), with first publication rights granted to the journal.

This is an open-access article distributed under the terms and conditions of the Creative Commons Attribution license (http://creativecommons.org/licenses/by/3.0/). 